\title{
ECONOMIC ANALYSIS ON MARKET POTENTIAL OF ETHIOPIAN RURAL MARKET
}

\author{
Shiferaw-Mitiku T. ${ }^{1}$, Shemelis-Zewdie Mersha ${ }^{2}$, Ushadevi K.N. ${ }^{3}$ \\ Ph.D Scholar, Kerala Agricultural University , College of Co-operation, Banking and \\ Management, Department of Rural Marketing Management, Vellanikkarra, \\ E-mail: shiferawsm@gmail.com
}

Lecturer at Ethiopian Civil Service University, Department of Social Security Management E-mail: shemelisz@gmail.com

Associate Professor \& Head, Department of Rural Marketing Management, College of Cooperation, Banking and Management, Kerala Agricultural University, Vellanikkarra E-mail: usha82.94@gmail.com

\begin{abstract}
Ethiopia has taken great strides to reduce poverty and increase the welfare of its largely rural, agricultural-based population. Ethiopia, a country with rural based economy mainly from Agriculture sector which contributed with the range of 42.5 percent to 67.25 percent of the GDP for the past two decades (1990-2012). Similarly, the percentage of Rural population against the total population of the country accounts a larger coverage; with 87.38 percent for the year 1990, 85.26percent during 2000 and 82.46 percent for the year 2013 . There is a steadfast growth in the total rural population from 41 million in 1990 and reached to 77.59 million in 2013 with average annual percentage growth rate of 2.8 for the past twenty three years. Very importantly, the major exportable products of the country is generated from the marketing of Agricultural produce such as coffee, khat, live animals, oilseeds, flowers, sesame, and also leather products. Above all, the consumption pattern and preference of rural consumer is changing due to the dynamic nature of marketing. However, marketers are failing to reach this largest target market of the population. This is mainly because, marketers are focusing on designing a product for urban market and when it becomes obsolete, it moves to the rural market. Indeed, it is unethical to override the marketing preference of the rural consumer. Recognizing the marketing requirements of the majority of the population would helps to bring a vibrant economic impact in the development of the nation. The present paper highlighted the major challenges and opportunities of Rural Marketing in Ethiopia, identified ways to explore the untapped Ethiopian Rural Market and identified possible recommendations and policy implications that would help to bring an improved development in the rural Ethiopia. Accordingly, the present article seeks the attention of Policy makers, Investors, Higher education curriculum developers and marketers to this vital area of development, to respond the call of the untapped Ethiopian Rural Market.
\end{abstract}

\section{KEY WORDS}

Agriculture; Ethiopia; Investment; Marketing; Rural marketing; Rural Ethiopia.

In the recent 2013 , the global rural population size accounted $47 \%$ of total population whereas, in Ethiopia, the percentage of rural population accounts 82.46 percent for the same year. Based on the share of employment contribution, Agriculture contributes 50 percent, Rural Non-farm sector contributes 32 percent and employment in Urban Ethiopia contributes only 18 percent. Similarly, the share of Gross Domestic Product (GDP) contribution; Agriculture accounted for 43 percent, Rural Non-Farm contributes 35 percent and urban contributes only 22 percent of the GDP of the country. Despite the increasing of rural population size and contribution of rural market (Agricultural and Rural non-farm) to the employment opportunity and GDP of the country; there is a gap of recognizing the marketing requirement of this vast market target.

Population growth without an equivalent growth in wealth and production would contribute to the decline in socioeconomic well-being, specially aggravated to the rural 
poverty and social inequality. In this regard, Ethiopia has taken remarkable steps on the level of socioeconomic development toward market-based reforms, such as trade regulation, privatization and an agricultural development-led industrialization. Despite measures taken to improve socioeconomic development of the nation, the approach was not very successful in increasing industrial output and food productivity. Therefore, the government introduced during the year 2010 a five-year Growth and Transformation Plan (GTP) aimed at building large road and railway systems and several new mega-dams for energy production and export so as to change the existing economic. From 2010 to 2013, GDP growth attained remarkable rates of $7 \%$ to $9 \%$ per year, at the same time inflation rates rose rapidly and trade imbalances and foreign debts accrued.

The construction of rural universities has continued, adding 13 new universities in addition to the existing 22 universities. However, construction of rural universities without a programme which is taking care of the marketing requirement of the majority of the population (82.46\%), rural consumer, attaining development can be a greater challenge. An effective safeguard against the development and transformation of rural economy through equipping professionals in a system that gears towards Rural Consumer (Rural market) is necessary.

According to the World Bank (2014), report on Agriculture and Rural Development, about 70 percent of the world's poor that live in rural areas, agriculture is the main source of income and employment. But depletion and degradation of land and water pose serious challenges to producing enough food and other agricultural products to sustain livelihoods of the rural populations and at the same time to meet the needs of urban populations from the rural based product. This indicates that the marketing requirement of urban market is dependent with rural market and a healthy and ethical marketing practice can happen when these two targets are moving in condition.

The effort taken by the government of Ethiopia to alleviate rural poverty and challenges of rural consumer is undeniable. However, despite the effort taken by the government to smooth the rural economy, there are areas where revisiting of marketing strategies for rural segment is required.

\section{OBJECTIVES OF STUDY}

Having the above challenges and existing problems in to account, the objectives of the present article are: to highlight the major challenges and opportunities of Rural Marketing in Ethiopia; to identify ways to explore the potential of the untapped Ethiopian Rural Market; to identify possible recommendations and policy implications to bring visible change in the rural Ethiopia.

\section{CHALLENGES AND OPPORTUNITIES OF ETHIOPIAN RURAL MARKET}

To the recent 2013, Ethiopia numbered among the world's least-developed countries, despite improvements in agriculture and services. The country is ranked 173 out of 186 countries on the Human Development Index (HDI, 2012). In 2011 and 2012, economic growth was substantial $(7.3 \%$ in 2011) which has led to continued high GDP growth and advances in health and education coverage; substantial infrastructure projects grew in intensity. The government has embarked on a robust expansion of basic health services in rural areas. Life expectancy rose from 45.7 years in the year 2001 to 58.7 years during 2010 . In general, living conditions improved slightly in health and education. However, the living conditions of the people, including the middle classes, have deteriorated mainly due to an extraordinary increase in the inflation rate from $8.1 \%$ in 2010 to $33.2 \%$ in 2011 ; with food inflation reaching $46 \%$, the highest rate in Africa.

According the State of Midwifery 2011, the country has one of the highest levels of unmet need for contraception in Africa and only 6 percent of births are attended by a skilled health worker. Maternal mortality has been steadily declining since 1990, but remains high. 
The lack of functioning health care facilities is severe, particularly in rural and isolated communities.

According to Oxfam (2012), only 18 percent of Ethiopian women are literate, compared to 42 percent of men. However, gender gaps in literacy are decreasing among the younger population. Urban/ rural differences are important for literacy rates approximately only 10 percent of rural women are literate, as against 60 percent of urban women. According to the 2011 Ethiopian Health and Demographics Survey, 52 percent of women and 38 percent of men have almost no education in their educational demographic profile. Urban women are far less likely to have no education $(28 \%)$ than rural women $(58 \%)$ and also further noted that, poverty is an important factor in educational attainment.

Ethiopia is endowed with a wide range of favourable agro-ecological zones and diversified resources that would enable to grow all types of Agricultural product like Food Crops, oil Crops, Beverage Crops, Horticulture, Cotton, Forestry and Apiculture, and Fishery as well as mining. However, the country remained heavily dependent on the performance of its dominant agricultural sector; covering $43 \%$ of the GDP, mainly in the production and marketing of coffee, khat, leather products, live animals, oilseeds. For the year 2012, the main Export partners of the country include China 13\%, Germany 10.8\%, US $7.9 \%$, Saudi Arabia $7.8 \%$ and Belgium 7.7 percent.

According fDilntelligence (2011), Ethiopia is one, among the top ten best overall ranked African countries in FDI attraction on the basis of Infrastructure, Economic potential, Business Friendliness, quality of life, FDI strategy, Human resource and best Effectiveness.

From the massive Foreign Direct Investment (FDI) flow to Ethiopia from 1992-2005, Agriculture particularly in cash crops farming and mixed food accounted $14.06 \%$ (5373.57 million Birr ${ }^{1}$ ) and 9.61\% (3671.8 million Birr) respectively (EIA, 2012).

The country also has potentially irrigable land which is estimated at 10 million hectares and is the largest livestock population in Africa. However, there are, investment opportunities which are potentially attractive for modern commercial livestock breeding, production and processing of meat, milk and eggs.

Regarding fishery, the country's fresh water bodies have an estimated annual fish production capacity of $30,000-40,000$ tons, of which less than ten percent is presently being exploited. This indicates Ethiopia seeks investors' attention with modern fisheries technologies so as to cover the demand of fish in the local and international market. Therefore, these all creates considerable opportunities for investors. According to Ethiopian Investment Authority (2005), the distribution of FDI flows to Ethiopia by sector from July 1992 to July 2005 the primary sector accounts $27.73 \%$ of the total FDI flow to the country having 259 projects with a capital of 10599.17 million Birr and of which, fishing accounts only $0.03 \%$ having only one project in number with a capital of 12.57 million Birr.

Additionally, Ethiopia is also a good destination for mining of natural resources. Ethiopia offers excellent opportunities for mineral prospecting and development. According to the Ethiopian Ministry of Mines and Energy, "Ethiopia's green stone belts offer one of the finest areas for gold mineralization anywhere in the world," and already more than 500 metric tons of gold deposits have been identified by Government exploration efforts. Additional gold reserves are expected to be identified in at least seven regions of the country. In addition to gold, Ethiopia is blessed with good deposits of tantalum, platinum, nickel, potash and soda ash and also construction and industrial minerals like marble, granite, limestone, clay, gypsum, gemstone, iron ore, coal, copper, silica, diatomite, bentonite, etc. With regard to fossil energy resources, there are significant opportunities for oil and natural gas in the four major sedimentary basins, namely the Ogaden, the Gambella, the Blue Nile and the Southern Rift Valley region of the country (EIA, 2005). However, according to Ethiopian Investment agency from July 1992 to July 20005 from the total capital flow of 38218.85 million Birr FDI flow into to the country, mining and quarrying accounts only $0.22 \%$ having 4 projects in number with a capital of 83.42 million Birr. This indicates that the available resource of the sector is not efficiently utilised by the domestic and foreign investors.

\footnotetext{
${ }^{1}$ Birr is the name of Ethiopian Currency
} 
The country has a lot to offer to tourists that would enable visitors to find awe-inspiring landscapes, historical sites and monuments. The highlands of Ethiopia have an attractive landscape, scenery and wildlife. In the African Rift Valley system, a wide variety of wildlife and numerous bird species, both endemic and common, are found and a substantial volume of traffic is directed to this area. The magnificent Tis Issat Falls on the Blue Nile (Abay) river the endemic wildlife in Semien Mountains, the Sof Omar Cave in the south east, the rockhewn churches at Lalibela, the ancient buildings of Yeha and the Obelisks at Axum, the medieval palaces at Gondar and the monasteries of Lake Tana, Debre Damo and Debre Libanos and also lake Langano and lake Awasa are the main interesting tourist attractions. Given its unique cultural heritage, magnificent scenery, pleasant climate, rich flora and fauna, important archaeological sites, friendly and hospitable people and the recent growth in the inflow of tourists, Ethiopia's potential puts it among the leading tourist destinations in Africa. However, tourism infrastructure, which is still inadequate, should be developed in order to cope with the growing traffic. Therefore, there are great opportunities for private investment in hotels, lodges and international restaurants that would attract tourists to make Ethiopia the top destination for tourist attraction. This is because; private investors in the area are still small in number. To make it clear, for the past fifteen years (1992 to 2005) the share of Hotel and Tourism from the total share of FDI flow to Ethiopia accounted only $2.86 \%$ having 98 number of project with a total capital of 1094.14 million Birr.

Rapid rural non-farm (including small market town) growth requires sufficient infrastructure (Ahmed et al., 2007; Haggblade, Hazell and Dorosh, 2007). Linking of Rural road networks as well as linking inter-regional roads with small market towns to major urban centers would helps to surplus agricultural producers and are crucial to enable efficient marketing of products. Likewise, electrification enhances production efficiency for producers of non-farm goods and services as well as improving quality of life (Ahmed,et.,al., 2007).

Communications networks, (mobile phone access or land-lines), also improves market efficiency by facilitating contacts between buyers and sellers and increased communications within vertically integrated marketing chains. However, the number of telephone usage of the country shows that, the total number of mobile phones in use up to the year 2013 is only 18 million which indicate that connection per 100 citizens is only 21.8 percent. According to the Ethiopian Telecommunication Corporation (ETC), the average of rural inhabitant of Ethiopia has to walk 30 kilometres to the nearest phone. However, during 2006 ETC announced a program to improve national coverage, and reduce the average distance to 5 kilometers and additionally, since 2008 CDMA2000 and WCDMA made available in certain areas (Haggblade, et.,al., 2007). According to the International Telecommunication Union (2012), the percentage of individuals using internet in Ethiopia is insignificant in number and one of lowest rates in the global rank. The percentage of individuals using internet in the country accounted only $0.02 \%$ of the population during the year 2000 and increased to $0.22 \%, 0.45$ $\%$ and $0.75 \%$ during the year 2005, 2008 and 2010 respectively. Since, telecommunications in Ethiopia is a monopoly in the control of Ethiotelecom, formerly the Ethiopian Telecommunication Corporation; all telephone service and internet access requires Ethiotelecom to be involved. Therefore, the marketing strategy of Ethiotelecom should be revisited to get used of the service provided to the majority of the population and to cater the untapped $99 \%$ of the population for internet facility and $78.2 \%$ for mobile.

The extraordinary contribution of Agriculture sector to the GDP of the country is hovering in the range of 42.5 percent to 67.25 percent for the past two decades (1990-2012); led to give further attention to the rural based economy. However, the contribution of the sector to the GDP is at decreasing trend. The government has to take measures in leveraging farmers through agricultural extension programme and market infrastructure support in order to insure food security issue in the country.

Ethiopian Agriculture and Rural Developments growth indicators shows that; there is a steadfast growth in the total rural population from 41 million in 1990 and reached to 77.59 million in 2013 with average annual percentage growth rate of 2.8 for the past twenty three years. Similarly, the percentage of rural population against the total population of the country 
accounts a larger coverage; with $87.38 \%$ for the year 1990, 85.26 during 2000 and lately in the year 2013 accounts for 82.46 percent.

The percentage of the Rural population with access to an improved water sources (drinking water) which includes piped water on premises (piped household water connection located inside the user's dwelling, plot or yard), and other improved drinking water sources (public taps or standpipes, tube wells or boreholes, protected dug wells, protected springs, and rainwater collection) accounted a cumulative annual percentage growth rate of $12 \%$ per year for the past two decades parallely with an impressive growth of rural population from 3.5 percent in 1990 to 42.1 percent in the year 2012. However, during the year 2011, the total percentage use of improved drinking water sources in the country was 49 percent. Of which, the percentage use of improved drinking water sources urban Ethiopia accounts for 96.6, whereas, rural Ethiopia accounts for 39.3 percent. This shows further attention is required to the rural Ethiopia in making drinking water sources accessible since it has adverse health impact on the nation.

\section{WAYS TO EXPLORE THE UNTAPPED ETHIOPIAN RURAL MARKET}

In order to stimulate agricultural growth and rural development in low-income countries need both private and public effort. The World Bank report 2008 (World Bank, 2007) indicated that, success in agricultural development requires a large number of investment and policy measures. Of which, creating market access to farmer and agro-industrials can play prominent role. This involves an enabling government policy, partner country policy, and investment in infrastructure and government services. The policies and investments are generally those that create an enabling environment for private investment in marketing, farm input supply, agro processing and, of course, farming itself. The investments are both private and public, with the latter focused on rural infrastructure, rural education, information supply, regulation and policy. In the second set of measures, emphasis to smallholder farming productivity, food production, reversing environmental degradation, and natural resource management, because smallholders have special information, infrastructure and support needs.

Investment in rural areas more broadly necessary as it can be taken as an incentive to rural youth to remain in rural area in stable condition by realizing employment opportunity. The kinds of strategies to boost agricultural growth and rural development through reducing poverty and improving food security in rural Ethiopia include:

- Investment in agricultural research and extension as well as linking farmers with Agricultural universities to deal with their affair. Research from higher institution should target the rural community concern as one of critical area to be dealt with.

- Making Rural Finance service accessible to the rural community to enable them to withstand with the challenge of seasonality and volatility of the price of Agricultural produce.

- Rural employment generation and support for non-farm small businesses through investment in smallholder farming, agro-industry, marketing and input supply.

- Creating market linkage for smallholder farmers and Agri-business through development of farmers' organizations, to help manage village level investment and to enable farmers to have a greater voice in national and local policy.

- Creating market infrastructure and conducting timely market intelligence study on major agricultural produce to save farmers from unexpected seasonal price cushion and to intensify the use of warehouse receipt service, which enable farmer in realizing better benefit out of his produce.

- Sustainable management of natural assets including forests, fisheries, pasture land and water resources through investor friendly approach and taking further marketing initiatives to break rough their contribution to the rural Ethiopia.

- Adopting agricultural policy, which avoids heavy government ownership and control of agricultural marketing, processing and input supply; agricultural price controls and 
agricultural export controls which might not affect the domestic market. The above mentioned are major areas that would help to unleash the potential of Ethiopian rural market to bring progressive growth in the socio-economic development of the country.

\section{RECOMMENDATIONS AND POLICY IMPLICATIONS}

Considerable attentions of policy makers, investors, curriculum developers, Academicians, researchers and marketers is required to this vital area of development; to explore the untapped Ethiopian rural Market. Accordingly, the following recommendations and policy implications might be taken in to consideration to place rural Ethiopian in the best position:

- Higher education institutions have to incorporate a programme that can address the marketing requirement of majority of population. In this regard, launching of Rural Marketing Management department in most of Ethiopian higher education institutions to produce professional who are able to recognize the challenges and marketing requirement of the Ethiopian Rural market is necessary. At the same time, both social science and natural science research can be best backed by participatory rural appraisal technique to pinpoint the challenges and solutions of the rural community and farmers in particular.

- Encouraging foreign and domestic investors to take initiative and reach the Ethiopian Rural market both private and public effort is required especially, in the value addition and marketing of agricultural produce, tourism and building of marketing infrastructure.

- Major challenges of the Ethiopian rural market should be taken as an opportunity for investment specially, in building infrastructural network such as road connectivity and distribution channels, telecommunication, electricity, and related challenge.

- Improving the income level realized by farmers is an important strategy to farmers and the rural community to withstand with the existing economic challenge and to contribute for the urban market. At same time, poverty reduction can be achieved through the use of improved agricultural technology and more intensive cropping patterns, use of modern agricultural imputes and giving special attention to marginal small holder farmers.

- Since communications networks, can improve market efficiency by facilitating contacts between buyers and sellers, the marketing strategies of Ethiotelecom should be revisited to cater almost $78.2 \%$ of the total population with mobile service and about $99 \%$ percent of the total population with internet service.

- Further marketing effort is required by the government to exploit the Ethiopian Rural market to fully utilise the available resources, in order to see the better Rural Ethiopia in condition.

\section{CONCLUSION}

Despite the effort made by the government of Ethiopia to combat poverty and to ensure food security of the nation, there is unprecedented challenge for the ever increasing large population size. To realize a better Ethiopia in the long run it is very important to pay attention to the majority of the target population, putting marketing effort to market the Rural Ethiopia. The contribution of rural economy, agriculture is the significant part of GDP of the country; and rapid agricultural growth is an effective tool in reducing poverty through revisiting the rural marketing strategies of the country in all sectors.

\section{REFERENCES}

1. Ahmed, Raisuddin, Steven Haggblade, Peter B.R. Hazell, Richard L. Meyer, and ThomasReardon. 2007. The Policy and Institutional Environment Affecting the Rural 
Nonfarm Economy. Chapter 11 in Haggblade, Hazell and Reardon, (eds.) Transforming the Rural Nonfarm Economy: Opportunities and Threats in the Developing World. Baltimore: Johns HopkinsUniversity Press.

2. Central Statistical Agency [Ethiopia] and (2012). Ethiopia Demographic and Health Survey 2011. Addis Ababa, Ethiopia Central Statistical Agency.

3. Ethiopian Investment Authority .2005. Ethiopian Investment Guide 2012.

4. www.fDilntelligence.com, 2011.African Countries of the Future 2011/12 winners.[Online] Available:http://www.invest.gov.ma/upload/documents/en_Doc_96.pdf [26-10-2013]

5. Haggblade, Steven, Peter B.R. Hazell and Paul A. Dorosh. 2007. "Sectoral Growth Linkages between Agriculture and the Rural Nonfarm Economy" in Haggblade, Steven, Peter B.R. Hazell and Thomas Reardon (eds.), Transforming the Rural Nonfarm Economy: Opportunities and Threats in the Developing World. Baltimore, MD: Johns Hopkins University Press.

6. International Telecommunication Union. 2012. The percentage of individuals using the internet 2000-2010.

7. John W. Mellor and Paul Dorosh. 2010 Agriculture and the Economic Transformation of Ethiopia. Ethiopia Strategy Support Program 2 (ESSP2). Working Paper No. ESSP 2 010.April 2010.

8. Kevin Cleaver 2013.The importance of scaling up for agricultural and rural development and a success story from Peru. IFAD Ocassional Paper 4.

9. Oxfam .2012. Coutry Profile: Ethiopia . [Online] Available: http://www.oxfam.ca/sites/ default /files/Country\%20Profile_Ethiopia.pdf [24-08-2014].

10. State of Midwifery 2011. Ethiopia http://www.unfpa.org/sowmy/resources/ docs/country_ info/ profile/en_Ethiopia_SoWMy_Profile.pdf [18-8-2014].

11. The Bertelsmann Stiftung's Transformation Index (BTI) .2014 . Ethiopia Country Report. [Online] Available: http://www.bti-project.org/reports/country-reports/esa/eth [18-8-2014].

12. World Bank 2013. World Development Indicators of Ethiopian Agriculture and Rural Development.

13. World Bank: 2014. Agriculture and rural development [Online] Available: http://data. worldbank. org/topic /agriculture-and-rural-development [18-8-2014]. 